\title{
Decline of lung function and development of chronic airflow limitation: a longitudinal study of non-smokers and smokers in Busselton, Western Australia
}

\author{
J K Peat, A J Woolcock, K Cullen
}

\begin{abstract}
Data collected during seven population health surveys over 18 years in Busselton, Western Australia, were examined to determine the effect of smoking on lung function and to investigate the development of chronic airflow limitation. Lung function was measured and details of respiratory illness and smoking histories were collected from subjects attending surveys at three year intervals from 1966 to 1984. Data from ex-smokers and asthmatic patients (diagnosis based on answer to questionnaire) were excluded. Regression of height adjusted forced expiratory volume in one second $\left(F E V_{1}\right)$ on age was calculated individually for 759 non-smokers and 225 regular smokers with four or more observations. Decline in height adjusted $\mathrm{FEV}_{1}$ was similar for men and women. In smokers the rate of decline in $\mathrm{FEV}_{1}$ was greater than in nonsmokers and was related to the amount smoked, to the extent that a smoker could expect a $20-30 \%$ greater rate of decline than a non-smoker of the same age. Chronic airflow limitation (defined as FEV $_{1} /$ FVC $<65 \%$ or FEV $_{1}<65 \%$ predicted on at least two occasions) was common, occurring in $24 \%$ of men and $18 \%$ of women who were regular smokers and in $5 \%$ of male and $8 \%$ of female nonsmokers. These figures are higher than those reported in other populations, especially for women and for nonsmokers. Not all chronic airflow limitation was associated with respiratory symptoms, confirming that the condition may be unrecognised until it is advanced.
\end{abstract}

Cigarette smoking is well recognised as a major cause of chronic airflow limitation. ${ }^{12}$ The effect of cigarette smoking and the development of chronic airflow limitation are usually assessed by change in forced expiratory volume in one second $\left(\mathrm{FEV}_{1}\right)$ in epidemiological studies. The natural decline of $\mathrm{FEV}_{1}$ with age is well documented $^{3}$ and in smokers is known to be affected adversely by the number of cigarettes smoked. $^{4-6}$

There is, however, a lack of data documenting lifetime change in $\mathrm{FEV}_{1}$ in individuals, and on the pattern of change in $\mathrm{FEV}_{1}$ in smokers, especially those who develop chronic airflow limitation. Cross sectional studies cannot be used to determine longitudinal changes ${ }^{7}$ and the number of longitudinal studies with frequent measurements over sufficiently long periods is limited. Because of the difficulties inherent in conducting longitudinal studies, most studies have used infrequent measures over periods of 4-12 years y $^{8-11}$ or have been limited to men or to occupational groups with a restricted age range. ${ }^{16-15}$ Several theoretical models of the effect of smoking on decline of $\mathrm{FEV}_{1}$ have been proposed on the basis of these data. ${ }^{6-18}$ It is now generally accepted that lung function in smokers shows a gradually accelerating decline from the early years of smoking rather than a rapid fall in $\mathrm{FEV}_{1}$ in later life. A relation between the level of $F E V_{1}$ and its rate of decline over time underlies the "horse racing effect" described by Fletcher et al." Thus susceptible smokers will have an $\mathrm{FEV}_{1}$ only slightly lower than non-smokers in their early smoking years but an obvious deterioration in lung function in middle age, and will then continue to have an accelerated decline in $\mathrm{FEV}_{1}$. This hypothesis has support from population studies showing that impaired lung function in middle life tends to precede chronic airflow limitation. ${ }^{19} 20$

The study of chronic airflow limitation is complicated by the fact that the condition develops in only a few smokers ${ }^{1}$ and is not restricted to smokers. ${ }^{1121}$ The causes of chronic airflow limitation in non-smokers and the distinguishing characteristics of smokers susceptible to the development of the condition are not known. Investigating the course of the decline in $\mathrm{FEV}_{1}$ in longitudinal population studies should help to determine the natural history of chronic airflow limitation and its associated aetiological factors.

We have analysed retrospectively data from the Busselton population study based on a general population sample at three year intervals from 1966 to 1981 . We report the changes in lung function in non-smokers and smokers that occurred over 18 years; the effect of age, sex, and cigarette smoking on rates of decline of $\mathrm{FEV}_{1}$; and the relation of age, sex, and respiratory symptoms to chronic airflow limitation.

\section{Methods} POPULATION

Busselton is $250 \mathrm{~km}$ south of Perth and has a Australia.

Accepted 5 October 1989 
population of about 6000 adults, all of whom were asked to take part in a population study every three years from 1966 to 1981. In 1981, 3940 attenders completed a questionnaire and had lung function measured and it is this group of subjects for whom we have obtained retrospective data. In 1984 data were collected from a restricted sample of 484 subjects only. All subjects completed a self administered questionnaire and had $\mathrm{FEV}_{1}$ and FVC measured at each attendance.

The questions, taken from the Medical Research Council questionnaire, ${ }^{22}$ related to respiratory and smoking history. Those considered to have a history of asthma were excluded from analysis. These were individuals who had ever answered "yes" to the question "Have you ever been diagnosed as having bronchial asthma?" or who answered "yes" in three or more of the studies to either of the questions "Have you ever had wheezing or tightness in the chest?" or "Have you ever had shortness of breath coming on while you are resting?" Five hundred and eight subjects (34\% of the non-asthmatic group) stopped smoking before or during the study and were classified as ex-smokers. These ex-smokers, together with pipe and cigar smokers, were also excluded from the analyses.

Non-smokers were defined as subjects who had never smoked regularly (one or more cigarettes a day) either before or during the study. Smokers were subjects who reported current regular smoking of one or more cigarettes a day in any of the studies, who continued to smoke and who were current smokers at the final study. They were divided into light and heavy smokers according to whether they smoked less than 20 or 20 or more cigarettes a day at the time of the final study. Only data from subjects classified as non-smokers or as smokers are reported here.

Subjects were classified as having respiratory symptoms if they answered "yes" in the 1981 or 1984 study to any of the following questions: "Have you ever had shortness of breath when hurrying on level ground?";

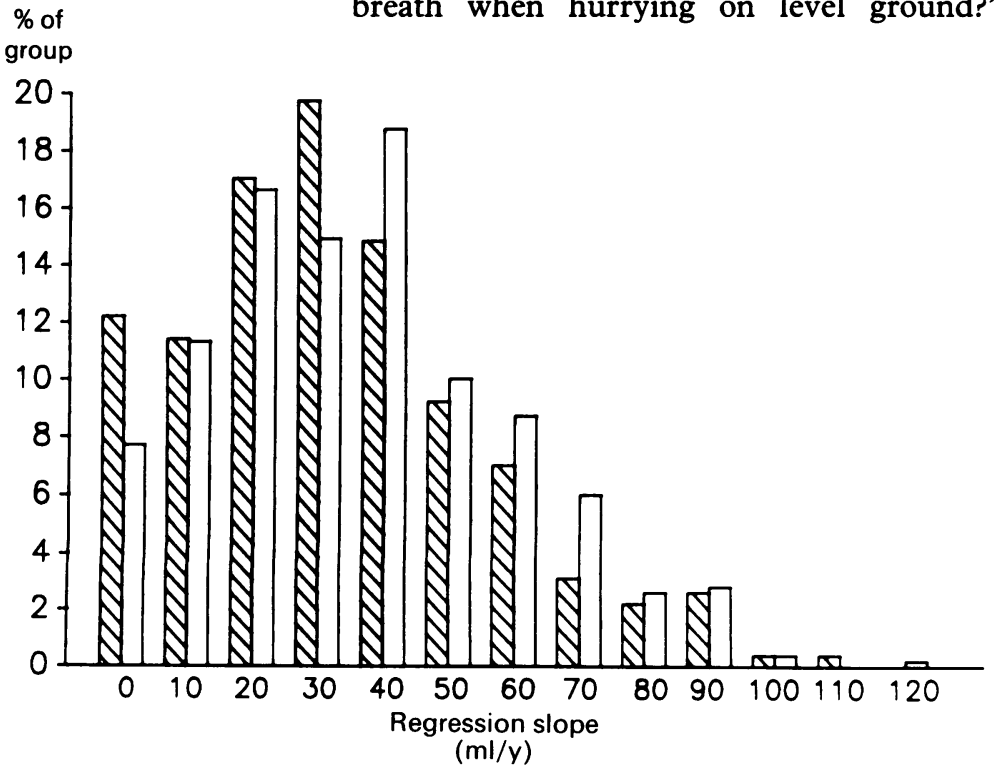

Figure 1 Distribution of regression slopes of height adjusted $F E V$, on age in male (匃) and female ( $\square$ ) non-smokers. The numbers on the $x$ axis are the minimum value for each interval.
"Have you ever had shortness of breath when walking up a hill?"; "Have you had cough with phlegm for as much as three months in a year?"

\section{LUNG FUNCTION}

$\mathrm{FEV}_{1}$ and forced vital capacity (FVC) were recorded on a dry bellows spirometer (a McKerrow spirometer from 1966 to 1978 and a Vitalograph ${ }^{R}$ spirometer in 1981 and 1984); all spirometers were calibrated at regular intervals to the same standard. Values are BTPS. At least two forced expiratory curves, reproducible to within $100 \mathrm{ml}$, were obtained from subjects in the standing position on each occasion.

Subjects who had an $\mathrm{FEV}_{1}$ less than $65 \%$ of the forced vital capacity $\left(\mathrm{FEV}_{1}{ }^{\circ} \mathrm{FVC}\right)$ or less than $65^{\circ}{ }_{0}$ of the value predicted ${ }^{23}$ in at least two studies were defined as having chronic airflow limitation. Subjects over 75 years were classified as having chronic airflow limitation only if they had an $\mathrm{FEV}_{1} \% \mathrm{FVC}$ ratio below $65^{\circ}$ before this age or if they also had an $\mathrm{FEV}_{1}$ below $65^{\circ}$, predicted. No subject had a low ${ }^{\circ}$ \% predicted $\mathrm{FEV}_{1}$ and a high $\mathrm{FEV}_{1}{ }_{0} \mathrm{FVC}$, indicating a restrictive disorder.

\section{STATISTICAL METHODS}

$\mathrm{FEV}_{1}$ was standardised for body size by dividing it by the cube of standing height $\left(\mathrm{FEV}_{1} /\right.$ $\mathrm{Ht}^{3}$ ) as height cubed correlated more closely with $\mathrm{FEV}_{1}$ than height squared. Individual regression coefficients were calculated by using a linear regression of $\mathrm{FEV}_{1} / \mathrm{Ht}^{3}$ on age for each subject; plots of data for individuals had shown that acceleration of loss of $\mathrm{FEV}_{1}$ over 10-18 years was slight so a linear regression describing change of $\mathrm{FEV}_{1} / \mathrm{Ht}^{3}$ with age was used to summarise the data from each individual. Linear regression over this period is judged to be sufficiently accurate. ${ }^{16}$ The rate of decline of $\mathrm{FEV}_{1}$ as denoted by the regression slope is referred to as $\mathrm{FEV}_{1}$ slope and expressed as $\mathrm{ml} / \mathrm{m}^{3} / \mathrm{y}$, or is simplified by standardising the data for a height of $1.7 \mathrm{~m}$ and expressing the result as loss of $\mathrm{FEV}_{1}$ in $\mathrm{ml} / \mathrm{y}$.

Stepwise multiple regression with $\mathrm{FEV}_{1}$ slope as the dependent variable was used to calculate the effects of age (in the final study), sex, and smoking on decline of FEV . Although the distribution of slopes for non-smokers was skewed (fig 1), examination of the standardised residuals showed only five values outside the normal distribution. Data analyses excluding these outliers showed that they did not influence the findings and analyses of the full data set are therefore presented.

\section{Results}

There were 759 non-smokers and 225 smokers who were non-asthmatic and who had sufficient data available for analysis. Of these subjects, $10^{\circ}{ }_{0}$ had data from seven studies, $61^{\circ}$, from six studies, and $29 \%$ from four or five studies.

Table 1 shows the percentage distribution of the sample by smoking history, sex, and age at the time of the final study. There were more female than male non-smokers but approxi- 
Table 1 Percentage distribution of smoking subgroups by age at last study and sex

\begin{tabular}{|c|c|c|c|c|c|c|c|}
\hline & & \multicolumn{5}{|c|}{ Age at last study (y) } & \multirow{2}{*}{$\begin{array}{l}\text { Total } \\
\text { number }\end{array}$} \\
\hline & & $<40$ & $40-49$ & $50-59$ & $60-69$ & $\geqslant 70$ & \\
\hline $\begin{array}{l}\text { Non-smokers } \\
\text { Light smokers } \\
\text { Heavy smokers } †\end{array}$ & $\begin{array}{l}\mathbf{M} \\
\mathbf{F} \\
\mathbf{M} \\
\mathbf{F} \\
\mathbf{M} \\
\mathbf{F}\end{array}$ & $\begin{array}{l}24 \cdot 5 \\
14 \cdot 2 \\
12 \cdot 1 \\
18 \cdot 5 \\
31 \cdot 7 \\
28 \cdot 0\end{array}$ & $\begin{array}{l}24 \cdot 9 \\
21 \cdot 5 \\
22 \cdot 4 \\
16 \cdot 7 \\
22 \cdot 2 \\
24 \cdot 0\end{array}$ & $\begin{array}{l}20 \cdot 5 \\
20 \cdot 2 \\
24 \cdot 1 \\
27 \cdot 8 \\
34 \cdot 9 \\
32 \cdot 0\end{array}$ & $\begin{array}{r}16 \cdot 2 \\
22 \cdot 3 \\
29 \cdot 3 \\
22 \cdot 2 \\
7 \cdot 9 \\
12 \cdot 0\end{array}$ & $\begin{array}{r}14 \cdot 0 \\
21 \cdot 9 \\
12 \cdot 0 \\
14 \cdot 8 \\
3 \cdot 2 \\
4 \cdot 0\end{array}$ & $\begin{array}{r}229 \\
530 \\
58 \\
54 \\
63 \\
50\end{array}$ \\
\hline
\end{tabular}

*One to 19 cigarettes a day.

† Twenty or more cigarettes a day.

FEV, slope $(\mathrm{ml} / \mathrm{y})$

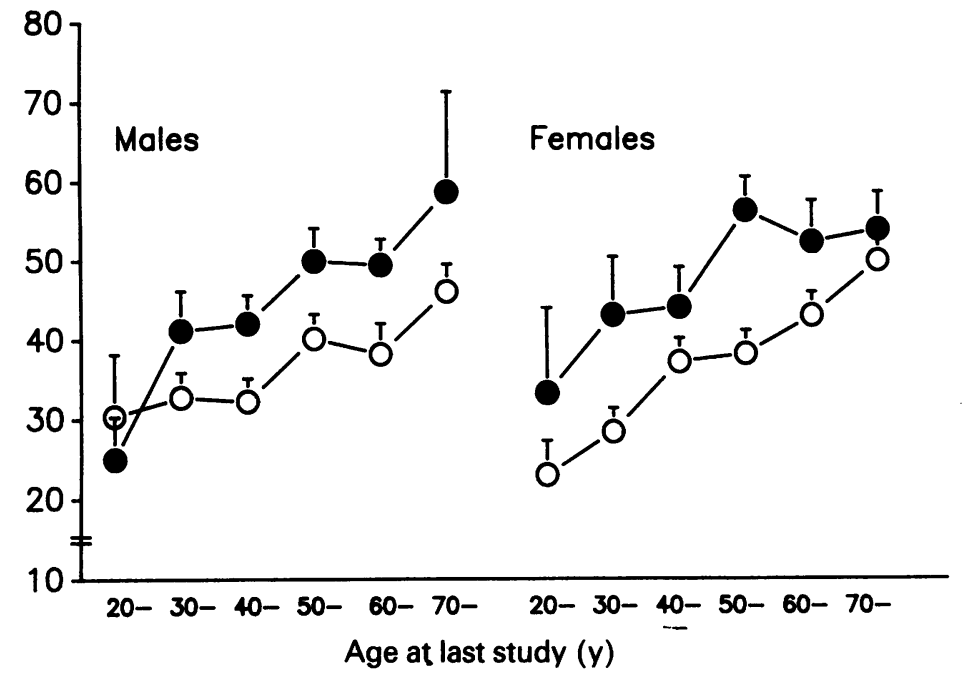

Figure 2 Mean FEV, slopes, shown with the standard error of the mean, in male and female non-smokers (O-O) and smokers (-O) divided into groups according to age at the time of the last study.

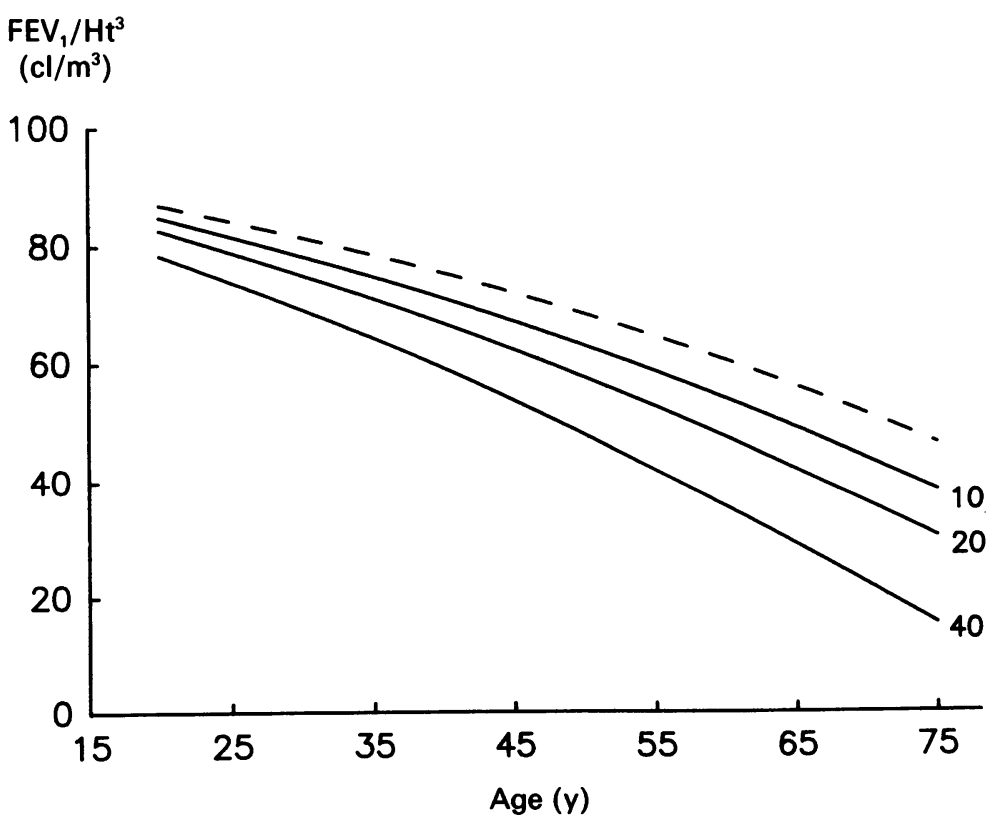

Figure 3 Fall in $\mathrm{FEV}, / \mathrm{Ht}^{3}$ with age in subjects (men and women combined) smoking 10,20 or 40 cigarettes per day, compared with the fall of $F E V$, with age for nonsmokers (broken line). The regression lines are obtained by integration of the regression equation of FEV, slope on age and amount smoked (given in text). mately equal numbers of male and female smokers. There was no significant difference in the age distribution of non-smokers and light smokers. More heavy smokers than nonsmokers were under 50 years of age (men $p<$ 0.05 , women $\mathrm{p}<0.01$ ).

Figure 1 shows the distribution of individual regression slopes of height adjusted $\mathrm{FEV}_{1}$ on age (FEV, slopes) in non-smokers, shown as positive values and representing rate of decline of $\mathrm{FEV}_{1}$ with time. Although some subjects had low rates of decline in $\mathrm{FEV}_{1}$, less than $2.0 \mathrm{ml} /$ $\mathrm{m}^{3} / \mathrm{y}(7 \mathrm{ml} / \mathrm{y})$, none of the subjects showed an increase in $\mathrm{FEV}_{1}$ during the period of study. The distribution of $\mathrm{FEV}_{1}$ slopes was unimodal and in non-smokers was skewed by a small proportion of subjects with a high rate of decline in $F_{E V}$. There was no significant difference in the distribution of slopes between men and women. The steepest slopes in nonsmokers were $110 \mathrm{ml} / \mathrm{y}$ in men and $121 \mathrm{ml} / \mathrm{y}$ in women and in smokers $123 \mathrm{ml} / \mathrm{y}$ in men and $122 \mathrm{ml} / \mathrm{y}$ in women.

Figure 2 shows that mean $\mathrm{FEV}_{1}$ slopes in non-smokers and smokers increased with age. In men the difference in mean $F E V_{1}$ slope between non-smokers and smokers was not apparent until after the age of 30 years; in women the difference was apparent in all age groups up to 70 .

Regression analyses with the slope of individual regression equations $\left(\mathrm{FEV}_{1}\right.$ slope) as the dependent variable were used to assess the relative contributions of age, sex, and smoking to rate of decline in $\mathrm{FEV}_{1}$. Age, entered as a continuous variable, and smoking, entered as a dummy variable, both had a significant effect on decline in $F E V_{1}$. No significant effect of sex was found $(t=1.29, \mathrm{p}<0.2)$ so the data for men and women are combined in the analysis. No significant interaction was found between amount smoked and age. When the variable for smoking was entered in the regression as number of cigarettes smoked daily at the time of the final study, the fit of the regression model improved significantly $(F=5 \cdot 82 ; 1981$ degrees of freedom), indicating that rate of decline was related to the current number of cigarettes smoked. The regression equation was:

$$
\begin{gathered}
\mathrm{FEV}_{1} \text { slope }=0.095 \text { (age) }-0.11 \text { (number of } \\
\text { cigarettes a day) }-2.78 \\
\mathrm{r}=0.33, \mathrm{SE}(\mathrm{B}) \text { age }=0.01, \mathrm{SE}(\mathrm{B}) \text { (number } \\
\text { of cigarettes a day) }=0.016
\end{gathered}
$$

Figure 3 shows a plot of the regression for non-smokers and subjects smoking 10,20, and 40 cigarettes a day. The plots were calculated by integrating the above regression equation and substituting a mean value for height adjusted $\mathrm{FEV}_{1}$ as a constant. To compare the outcome in lung function for non-smokers and smokers beginning with the same lung function, the mean value of height adjusted $\mathrm{FEV}_{1}$ at age 25 years, calculated from the data for each group, was used as the constant. The regression lines for smokers fell below the line for nonsmokers by an amount that depended on the number of cigarettes smoked.

Table 2 shows the age adjusted mean annual decline in $\mathrm{FEV}_{1}$, calculated for a man of height 
Table 2 Comparison of decline of $F E V_{1}(\mathrm{ml} / \mathrm{y})$ in the present study with results from other studies (men only)

\begin{tabular}{|c|c|c|c|c|}
\hline First author & Age (y) & Non-smokers & $\begin{array}{l}\text { Light } \\
\text { smokers }\end{array}$ & $\begin{array}{l}\text { Heavy } \\
\text { smokers* }\end{array}$ \\
\hline $\begin{array}{l}\text { Higgins }{ }^{38} \\
\text { Ferris }^{39}\end{array}$ & $\begin{array}{l}37-49 \\
25-34 \\
55-64\end{array}$ & $\begin{array}{l}23 \\
19 \\
29\end{array}$ & $\begin{array}{l}40 \\
33 \\
40\end{array}$ & $\begin{array}{ll}41 & (15 \mathrm{~g}) \\
34 & (25) \\
49 & \end{array}$ \\
\hline $\begin{array}{l}\text { Fletcher' }^{1} \\
\text { Bande }^{12}\end{array}$ & $\begin{array}{l}30-59 \\
18-55\end{array}$ & $\begin{array}{l}21 \\
27\end{array}$ & $\begin{array}{l}29 \\
30\end{array}$ & $\begin{array}{ll}34 & (15) \\
39 & (20)\end{array}$ \\
\hline Beaty ${ }^{14}$ & $\begin{array}{l}40-49 \\
50-59 \\
60+ \\
40-64\end{array}$ & $\begin{array}{l}27 \\
52 \\
31 \\
33\end{array}$ & $\frac{-}{51} \quad$ (all smokers) & $\begin{array}{l}39 \ddagger \\
55 \\
79\end{array}$ \\
\hline $\begin{array}{l}\text { Huhti }{ }^{9} \\
\text { Pride }^{17} \dagger \\
\text { Present study } \dagger\end{array}$ & $\begin{array}{l}40-64 \\
\ddagger \\
40 \\
50 \\
60\end{array}$ & $\begin{array}{l}33 \\
23 \\
32 \\
37 \\
41\end{array}$ & $\begin{array}{ll}51 & \text { (all smokers) } \\
35 & \\
41 & \\
48 & \\
50 & \end{array}$ & $\begin{array}{l}44 \ddagger \\
43 \quad(20) \\
48 \\
53\end{array}$ \\
\hline
\end{tabular}

ऋThe minimum number of cigarettes or grams of tobacco smoked a day used to define heavy smokers is given in parentheses.

+ Calculations for a man of $170 \mathrm{~cm}$

$\ddagger$ No information given.

$170 \mathrm{~cm}$, compared with values reported by other workers for non-smokers and light and heavy smokers (the latter variously defined as smoking from 15 to 25 cigarettes or $15 \mathrm{~g}$ tobacco a day). The values obtained in the present study were within the range found in previous studies.

Table 3 shows the prevalence of chronic airflow limitation and respiratory symptoms in non-smokers and smokers. There was significantly more chronic airflow limitation in the smokers (men $23.6 \%$, women $17.8 \%$ ) than in the non-smokers (men $5 \cdot 2 \%$, women $7 \cdot 6 \%$ ) $(p<0.001)$. The prevalence of respiratory symptoms was also higher in smokers $(p<$ 0.001 ). In subjects with chronic airflow limitation the proportion of non-smokers and smokers who reported respiratory symptoms appeared similar, though the results are influenced by small numbers of subjects with chronic airflow limitation in the lower age groups. Non-smokers with chronic airflow limitation were on average older than smokers: $57 \%$ were 70 years or older at the time of the final study compared with $21 \%$ of smokers ( $p$ $<0.001$ ).

\section{Discussion}

This study provides further documentation of the decline in lung function in adult life in smokers and non-smokers, and quantifies the role of cigarette smoking in reducing lung function and causing chronic airflow limitation and disability. We found that the rate of decline of lung function in smokers, as a group, was more rapid than that of non-smokers and was related to the amount smoked. Thus, in general, a smoker may expect to have lower lung function than a non-smoker of the same height and age and a more rapid decline in lung function.

This longitudinal study includes data for a large number of subjects seen at regular intervals over 9-18 years. Although the entire population of Busselton was asked to attend each study, attendance bias resulted in an excess of female non-smokers and of older people. Our prevalence figures should therefore be interpreted with caution. Nevertheless, because the $\mathrm{FEV}_{1}$ data were collected from subjects without clinically severe disease living in a town without manufacturing industry, the results relating to lung function are relevant to a general population living in an environment free of industrial pollutants.

We defined chronic airflow limitation as an $\mathrm{FEV}_{1} \% \mathrm{FVC}$ or $\mathrm{FEV}_{1} \%$ predicted of less than $65 \%$ on at least two occasions. Use of an $\mathrm{FEV}_{1}$ less than $65 \%$ of predicted to define chronic airflow limitation is consistent with other studies. ${ }^{511}$ We included a low $\mathrm{FEV}_{1} \% \mathrm{FVC}$ in our definition because this measure detects obstruction in individuals with FVC above the predicted value. We used a stricter definition for subjects over 75 years because an $\mathrm{FEV}_{1} \%$ FVC of $65 \%$ is within the normal range at this age. Thus only subjects with definite chronic airflow limitation, present for at least four years, were included in our definition. Chronic airflow limitation develops slowly and many subjects not classified as having this condition may have had early chronic airflow limitation with mild degrees of lung function abnormality.

Values for decline in $\mathrm{FEV}_{1}$ in both nonsmokers and smokers in this study are similar to values from other studies for subjects aged less than 60 years. Although decline in $\mathrm{FEV}_{1}$ had a significant association with age and number of cigarettes smoked, $90 \%$ of the variation in $\mathrm{FEV}_{1}$ slope remains unexplained. The finding that height, age, and smoking history account for only $10 \%$ of the variation is consistent with the results of other studies. ${ }^{61424}$

We found that, when $\mathrm{FEV}_{1}$ was adjusted for

Table 3 Prevalence of symptoms and chronic airflow limitation (CAL) according to age at last study and whether smoker or non-smoker

\begin{tabular}{|c|c|c|c|c|c|c|c|}
\hline & \multirow[b]{2}{*}{ Smoking } & \multicolumn{5}{|c|}{ Age at last study (y) } & \multirow[b]{2}{*}{ Total } \\
\hline & & $<40$ & $40-49$ & $50-59$ & $60-69$ & $\geqslant 70$ & \\
\hline Total & $\begin{array}{l}\text { Smoker } \\
\text { Non-smoker }\end{array}$ & $\begin{array}{r}131 \\
51\end{array}$ & $\begin{array}{r}171 \\
48\end{array}$ & $\begin{array}{r}154 \\
67\end{array}$ & $\begin{array}{r}155 \\
40\end{array}$ & $\begin{array}{r}148 \\
19\end{array}$ & $\begin{array}{l}759 \\
225\end{array}$ \\
\hline \multicolumn{8}{|l|}{${ }_{0}{ }_{0}$ with symptoms ${ }^{\star}$} \\
\hline & $\begin{array}{l}\text { Non-smoker } \\
\text { Smoker }\end{array}$ & $\begin{array}{l}13 \cdot 7 \\
25 \cdot 5\end{array}$ & $\begin{array}{l}13 \cdot 5 \\
39 \cdot 6\end{array}$ & $\begin{array}{l}22 \cdot 7 \\
44 \cdot 8\end{array}$ & $\begin{array}{l}34.9 \\
37.5\end{array}$ & $\begin{array}{l}33 \cdot 1 \\
36 \cdot 8\end{array}$ & $\begin{array}{l}23 \cdot 6 \\
37 \cdot 3\end{array}$ \\
\hline \multirow{2}{*}{$\begin{array}{l}{ }_{\circ} \text { with CAL } \\
{ }_{\circ}^{\circ} \text { of CAL subjects with } \\
\text { symptoms }\end{array}$} & $\begin{array}{l}\text { Non-smoker } \\
\text { Smoker }\end{array}$ & $\begin{array}{l}2 \cdot 3 \\
2 \cdot 0\end{array}$ & $\begin{array}{r}1.8 \\
12.5\end{array}$ & $\begin{array}{r}2 \cdot 6 \\
31 \cdot 3\end{array}$ & $\begin{array}{r}9 \cdot 0 \\
25 \cdot 0\end{array}$ & $\begin{array}{l}26 \cdot 1 \\
52 \cdot 6\end{array}$ & $\begin{array}{r}7 \cdot 4 \\
21 \cdot 3\end{array}$ \\
\hline & $\begin{array}{l}\text { Non-smoker } \\
\text { Smoker }\end{array}$ & $\begin{array}{r}66 \cdot 7 \\
100 \cdot 0\end{array}$ & $\overline{33} \cdot 3$ & $\begin{array}{l}50 \cdot 0 \\
61.9\end{array}$ & $\begin{array}{l}42 \cdot 9 \\
30 \cdot 0\end{array}$ & $\begin{array}{l}34 \cdot 0 \\
30 \cdot 0\end{array}$ & $\begin{array}{l}37 \cdot 5 \\
45 \cdot 8\end{array}$ \\
\hline
\end{tabular}

^Shortness of breath on exertion or persistent cough. 
height, the rate of decline in women was similar to that in men and affected similarly by smoking. Relatively few longitudinal studies have included women in their samples and, in those that have, different methods of data presentation preclude comparisons. In a five year longitudinal study Beck et $a l^{24}$ found that women had less loss of $\mathrm{FEV}_{1}$ with age than men and concluded that the difference was explained by their smoking fewer cigarettes. More recently, Camilli et al ${ }^{25}$ reported that men are more likely to have a decline in $\mathrm{FEV}_{1}$ of $100 \mathrm{ml} / \mathrm{y}$ or more (unadjusted for height), suggesting that the effect of smoking is less in women. Because the rate of decline of unadjusted $\mathrm{FEV}_{1}$ is steeper in taller people, ${ }^{12}$ the finding of lower rates of decline of unadjusted $\mathrm{FEV}_{1}$ in women ${ }^{11}{ }^{146}$ would be expected.

It has been reported that the $F E V_{1}$ slopes in smokers who are not susceptible to chronic airflow limitation are likely to be only slightly different from those of non-smokers. ${ }^{16}$ Our data, however, indicate that on average, smokers can expect a $20-30 \%$ greater rate of decline than non-smokers of the same age. In a general population study Higgins et $a l^{519}$ showed that a low $\mathrm{FEV}_{1}$ in middle life was a strong predictor of the risk of developing chronic airflow limitation and that, by comparison, the predictive value of the number of cigarettes smoked was relatively small. In a study of male smokers Burrows et al ${ }^{20}$ found that a low $\mathrm{FEV}_{1} \% \mathrm{FVC}$ was uniformly associated with a high rate of $\mathrm{FEV}_{1}$ decline. The evidence that reduced lung function in middle age tends to precede chronic airflow limitation, taken with our findings that $\mathrm{FEV}_{1}$ slopes form a continuum, that $\mathrm{FEV}_{1}$ decline increases with age, and that very few smokers have excessively steep rates of decline, supports the "tracking" theory-that the decline in $\mathrm{FEV}_{1}$ accelerates gradually and that the $F E V_{1}$ of susceptible smokers might not be abnormal until late middle age. Because rate of decline is related to amount smoked, the degree of tracking in smokers is likely to relate to smoking history.

Because of exclusions due to severe disease and to a "survivor" effect, ${ }^{1724}$ population studies tend to underestimate the effects of smoking on lung function, particularly in the older age groups. In this population there was a low prevalence of smokers $(15 \%)$ and a high prevalence of ex-smokers $(34 \%)$. Although decline in $\mathrm{FEV}_{1}$ increased with age, there were no smokers over 60 years of age with an FEV loss greater than $100 \mathrm{ml} / \mathrm{y}$. The smokers may have been a self selected group who were able to continue smoking because of good health. Possibly smokers with a steep decline in $\mathrm{FEV}_{1}$ had stopped smoking or their poor lung function prevented them from attending-or they may have died from smoking related diseases.

Previous studies may have underestimated the prevalence of chronic airflow limitation. Although our study was not designed to assess the prevalence of respiratory illness accurately, we found a higher prevalence of chronic airflow limitation than previous studies, especially in non-smokers and in women. Among the men $24 \%$ of the regular smokers had chronic airflow limitation. Previous estimates suggest that only $10-20 \%$ of men who are heavy smokers develop chronic airflow limitation, ${ }^{11}$ though exclusion of subjects aged 60 or 70 years may in part explain this lower prevalence. Chronic airflow limitation is reported to occur more commonly in men than in women, ${ }^{27}$ but its occurrence in women has rarely been investigated. The prevalence of the condition in women smokers in our study was $18 \%$, almost as high as in men. We also found that $7 \%$ of non-asthmatic non-smokers had chronic airflow limitation, compared with a prevalence of $4 \%$ in a study by Krzyzanowski et al. ${ }^{11}$ Although asthma and smoking remain the most important identified causes of chronic airflow limitation ${ }^{122829}$ apparently the condition may develop in the absence of these factors and to a similar extent in women. Its causes, particularly in non-smokers, require further investigation.

Most subjects with chronic airflow limitation $(62 \%$ of non-smokers and $54 \%$ of smokers) did not report shortness of breath or persistent cough with phlegm. Thus symptoms may not occur, and the disease may go unrecognised until severe and irreversible loss of $\mathrm{FEV}_{1}$ has taken place. Dyspnoea has been shown to occur when the $F E V_{1}$ has fallen to below 1.5 or 2.0 litres $^{30}$ so that, in smokers with an $\mathrm{FEV}_{1}$ decline of $80-100 \mathrm{ml}$ a year, 20 years may elapse before the reduction in $\mathrm{FEV}_{1}$ is sufficient to cause shortness of breath.

This study presents data to confirm that lung function in smokers, as a group, declines more rapidly than that of non-smokers. The effects of cigarette smoking, as a modifiable factor, have been extensively investigated and improvement in lung function has been shown to follow a decrease in smoking. ${ }^{101324}$ Further studies are required to determine the point at which a steep rate of decline can be tempered and to determine the characteristics that indicate that the course of the disease is largely irreversible.

This study has shown that steep rates of decline are not limited to men or to smokers, and not necessarily associated with respiratory symptoms, though chronic airflow limitation may be expected to result in disability eventually. In this context relatively little attention has been given to factors other than smoking, such as childhood events, ${ }^{31} 32$ physiological characteristics,,$^{51733-35}$ or environmental and social conditions, ${ }^{17}$ which are known to affect lung function and which may play a part in the development of chronic airflow limitation. In particular, bronchial hyperresponsiveness is associated with chronic airflow limitation ${ }^{21}$ and reduced lung function ${ }^{36}$ and its role deserves further investigation. Because the condition is a common cause of disability and a risk factor for other serious illness, ${ }^{37}$ and because it has been impossible to prevent smoking in whole populations or alter the course of the disease by other means, identification of those at high risk remains an essential health care issue.

We would like to thank the Busselton Population Study for allowing us to analyse retrospec- 
tive data and the Australian Tobacco Research Foundation for its financial assistance. We would also like to thank Ms Victoria Keena for editorial assistance with the manuscript and $\mathrm{Mr}$ John Reynolds for preparing the figures.

1 Fletcher C, Peto R, Tinker C, Speizer FE. The natural history of chronic bronchitis and emphysema. Oxford: Oxford University Press, 1976.

2 Barter CE, Campbell AH. Relationship of constitutional factors and cigarette smoking to decrease in 1-second forced expiratory volume. Am Rev Respir Dis 1976;113: 305-14.

3 Burrows B, Cline MG, Knudson RJ, Taussig LM, Lebowitz MD. A descriptive analysis of the growth and decline of the FVC and FEV 1 . Chest 1983;5:717-24.

4 Burrows B, Knudson RJ, Cline MG, Lebowitz MD Quantitative relationships between cigarette smoking and ventilatory function. Am Rev Respir Dis 1977;115: 195-205.

5 Higgins MW, Keller JB, Becker M, et al. An index of risk for obstructive airways disease. Am Rev Respir Dis 1982; 124:144-51.

6 Kauffman F, Drouet D, Lellouch J, Brille D. Twelve years spirometric changes among Paris area workers. Int Epidemiol 1979;8:201-12.

7 Glindmeyer HW, Diem JE, Jones RN, Weill H. Noncomparability of longitudinally and cross-sectionally determined annual change in spirometry. Am Rev Respir Dis 1982;125:544-8.

8 Huhti E, Ikkala J. A 10-year follow-up study of respiratory symptoms and ventilatory function in a middle-aged rura population. Eur J Respir Dis 1980;61:33-45.

9 Bosse R, Sparrow D, Garvey AJ, Costa PT, Weiss ST, Rowe JW. Cigarette smoking, ageing, and decline in pulmonary function: a longitudinal study. Arch Environ Health 1980; 35:247-52.

10 Bosse R, Sparrow D, Rose CL, Weiss ST. Longitudinal effect of age and smoking cessation on pulmonary function. Am Rev Respir Dis 1981;123:378-81.

11 Krzyzanowski M, Jedrychowski W, Wysocki M. Factor associated with the change in ventilatory function and the development of chronic obstructive pulmonary disease in a 13-year follow-up of the Cracow study. Risk of chronic obstructive pulmonary disease. Am Rev Respir Dis 1986, 134:1011-9.

12 Bande J, Clement J, Van de Woestijne KP. The influence of smoking habits and body weight on vital capacity and FEV, in male Air Force personnel: a longitudinal and FEV ${ }_{1}$ in male Air Force personnel: a longitudinal and cross-secti

13 Hughes JA, Hutchinson DCS, Bellamy D, Dowd DE, Ryan $\mathrm{KC}$, Hugh-Jones $\mathrm{P}$. The influence of cigarette smoking and its withdrawal on the annual change of lung function in pulmonary emphysema. $Q J$ Med 1982;202:115-24.

14 Beaty TH, Menkes HA, Cohen BH, Newill CA. Risk factors associated with longitudinal change in pulmonary function. Am Rev Respir Dis 1984;129:660-7.

15 Campbell AH, Barter CE, O'Connell JM, Huggins R. Factors affecting the decline of ventilatory function in Factors affecting the decline of ventilatory
chronic bronchitis. Thorax 1985;40:741-8.

16 Fletcher C, Peto R. The natural history of chronic airflow obstruction. $B r$ Med $J$ 1977;1:1645-8.

17 Pride NB. Smoking and the development of progressive airflow obstruction. Ann Acad Med 1985;14:496-502.

18 Dockery DW, Speizer FE, Ferris BG, Ware JH, Louis TA, Spiro A III. Cumulative and reversible effects of lifetime smoking on simple tests of lung function in adults. $A m R e v$ Respir Dis 1988;137:286-92.
19 Higgins MW, Keller JB, Landis R, et al. Risk of chronic obstructive pulmonary disease. Collaborative assessment of the validity of the Tecumseh index of risk. Am Rev Respir Dis 1984;130:380-5.

20 Burrows B, Knudson RJ, Camilli AE, Lyle SK, Lebowitz $M D$. The "Horse-Racing Effect" and predicting decline in forced expiratory volume in one second from screening spirometry. Am Rev Respir Dis 1987;135:788-93.

21 Yan K, Salome CM, Woolcock AJ. Prevalence and nature of bronchial hyperresponsiveness in subjects with chronic obstructive pulmonary disease. Am Rev Respir Dis 1985 132:25-9.

22 Medical Research Council Committee on the Aetiology of Chronic Bronchitis. Definition and classification of chronic bronchitis for clinical and epidemiological purposes. Lancet 1965; ;:775-9.

23 Morris JF, Koski A, Johnson LC. Spirometric standards for healthy non-smoking adults. Am Rev Respir Dis 1971;103. $57-67$.

24 Beck GJ, Doyle CA, Schachter EN. Smoking and lung function. Am Rev Respir Dis 1981;123:149-55.

25 Camilli AE, Burrows B, Knudson RJ, Lyle SK, Lebowitz $M D$. Longitudinal changes in forced expiratory volume in one second in adults. Effects of smoking and smoking cessation. Am Rev Respir Dis 1987;135:794-9.

26 van der Lende R, Kok TJ, Peset Reig R, Quanjer PhH Shouten JP, Orie NGM. Decreases in VC and FEV, with time: indicators for effects of smoking and air pollution. Bull Eur Physiopath Respir 1981;17:775-92.

27 Burrows B, Earle RH. Course and prognosis of chronic obstructive lung disease. A prospective study of 200 patients. N Engl J Med 1969;280:397-404.

28 Brown PJ, Greville HW, Finnucane KE Asthma and irreversible airflow obstruction. Thorax 1984;39:131-6.

29 Peat JK, Woolcock AJ, Cullen K. Rate of decline of lun function in subjects with asthma. Eur J Respir Dis 1987 70:171-9.

30 Speizer FE, Tager IB. Epidemiology of chronic mucus hypersecretion and obstructive airways disease. Epidemiol $\operatorname{Rev} 1979 ; 1: 124-42$.

31 Tager JB, Weiss ST, Rosner B, Speizer FE. Effect of parental cigarette smoking on the pulmonary function of children. Am J Epidemiol 1979;110:15-26.

32 Burrows B, Knudson RJ, Lebowitz MD. The relationship of childhood respiratory illness to adult obstructive airways disease. Am Rev Respir Dis 1977;115:751-60.

33 Kauffman F, Neukirch F, Korobaeff M, Marne MJ, Claude JR, Lellouch J. Eosinophils, smoking and lung function. An epidemiologic survey among 912 working men. $A m$ Rev Respir Dis 1986;134:1172-5.

34 Burrows B, Lebowitz MD, Barbee RA, Knudson RJ, Halonen $M$. Interactions of smoking and immunologic factors in relation to airways obstruction. Chest 1983; 84:657-61.

35 Connellan SJ, Joyce H, Holland F, Carson R, Pride NB Factors determining susceptibility to chronic airway narrowing in smokers. Thorax 1982;37:232.

36 Taylor RG, Joyce H, Gross E, Holland F, Pride NB. Bronchial reactivity to inhaled histamine and annual rate of decline in $\mathrm{FEV}_{1}$ in male smokers and ex-smokers. Thorax 1985;40:9-16.

37 Tockman MS, Anthonisen NR, Wright EC, Donithan MG Airways obstruction and the risk for lung cancer. Ann Intern Med 1987;106:512-8.

38 Higgins ITT, Gilson JC, Ferris BG Jr, Waters ME, ampbell H, Higgins $\mathrm{MW}$. Chronic respiratory disease in an industrial town: a nine--

39 Ferris BG Jr, Chen J, Puleo S, Murphy RLH Jr. Chronic nonspecific respiratory disease in Berlin, New Hampshire 1967 to 1973. A further follow-up study. Am Rev Respir Dis 1976;113:475-85. 